\title{
SCHIFF BASE OF ISATIN AND ITS CHROMIUM METAL COMPLEX: SYNTHESIS, CHARACTERIZATION AND BIOLOGICAL EVALUATION
}

\author{
Suman Kumari, Seema and Mamta Ranka $a^{凶}$ \\ Department of Chemistry, University of Rajasthan, \\ Jaipur-302 004, (Rajasthan) India \\ ${ }^{\square}$ Corresponding Author: mmt31ran@gmail.com
}

\begin{abstract}
Schiff bases are excellent biological active compounds due to the presence of $\mathrm{N}, \mathrm{O}$, or $\mathrm{S}$ as heteroatoms prepared by the condensation reaction of carbonyl compounds (aldehyde or ketone) with a primary amine. Isatin Schiff bases found to possess several biological as well as pharmacological activities. ${ }^{1-3}$ Our present work reports synthesis and characterization of Isatin-3-phenylhydrazone (IPH) and its metal complex $\left[\mathrm{CrL}_{2} \mathrm{Cl}_{2}\right]$. Various techniques include physiochemical Analysis, elemental Analysis, magnetic moment measurement, spectral techniques (FTIR, UV-Vis, ${ }^{1} \mathrm{H}-\mathrm{NMR}$ ), etc., have been employed to characterize both ligand and complex. Since Isatin-3-phenylhydrazone Schiff base has already been reported to show antimicrobial activity ${ }^{4}$ against various bacteria such as $S$. aureus, B. subtilus, Enterococcus D, E. coli, P. vulgaris etc., hence, both synthesized ligand and complex are evaluated for antibacterial and antifungal activity against particular bacterial and fungal strains and results obtained were compared with the standards. Further, we are concerned with the ligand's pharmacological action and its metal complex with enhanced efficiency and minimal side effects.
\end{abstract}

Keywords: Isatin-3-phenylhydrazone, Schiff Base, Metal Complex, Spectral Techniques, Pharmacological

RASĀYAN J. Chem., Vol. 14, No.1, 2021

\section{INTRODUCTION}

Isatin is among the most important heterocyclic compound. Isatin and its derivatives attracted more attention in the medical field due to their strong efficiency in biological and pharmacological areas. Isatin ring, as a significant pharmacophore in drug discovery, has already been reported. ${ }^{5}$ Schiff and Mannich bases of isatin are also previously reported to show a wide range of biological and therapeutic properties. ${ }^{6}$ Isatin derivatives exhibit various biological activities like antimicrobial ${ }^{7,8}$, antiviral $^{9}$, antitumor ${ }^{10}$, anti-HIV ${ }^{11}$, antitubercular ${ }^{12}$, anti-inflammatory ${ }^{13}$, anticonvulsant ${ }^{14}$ etc. Among all isatin derivatives, Isatin-3-phenylhydrazone Schiff base is an excellent chelating agent due to their ease of synthesis, flexibility for synthesis and characteristic effect of $-\mathrm{C}=\mathrm{N}$ (azomethine) moiety, the ability to form chelates with various metal ions and also can attune the ligation aspects by varying denticity and basicity. All the above studies and reviews prompt us to synthesize isatin derivative i.e., Isatin-3-phenylhydrazone employing a method different from the reported method. Further, the ligand is used for complexation with chromium salt. Later, all prepared compounds are biologically screened against certain microbes.

\section{Materials and Instrumentation}

\section{EXPERIMENTAL}

All the reagents, solvents, and chemicals utilized were of A.R. grade with the highest purity. Isatin, phenylhydrazine hydrochloride, and metal salt $\left(\mathrm{CrCl}_{3} \cdot 6 \mathrm{H}_{2} \mathrm{O}\right)$ used were purchased from Sigma Aldrich. Melting points of synthesized ligand and complex determined in open capillaries and were reported unrectified. Elemental Analysis of Carbon, Hydrogen, Nitrogen, and Chlorine was done by the CHNX method. Chromium was estimated by the EDTA method. Molecular weights were determined by the RAST method. FTIR spectra of ligand and complex recorded on Model PerkinElmer FT-IR Spectrometer employing $\mathrm{KBr}$ pellets. Electronic absorption spectra were recorded in ethanol engaging Perkin Elmer Lambda UV 750 UV/VIS Spectrometer in the range of 200-700 nm wavelengths. Nuclear magnetic resonance $\left({ }^{1} \mathrm{HNMR}\right)$ spectra were taken in DMSO solution with a Jeol Resonance ECS-400 Spectrometer at $400 \mathrm{MHz}$. Gouy Balance model no: HO-ED-EM-08 was used for magnetic moment measurements. For calculation of molar conductance of complex, Systronics Direct Reading Conductivity Meter-304 was employed having glass cell (cell constant $=1.0 \mathrm{~cm}^{-1}$ ) in 
DMSO. The purity of synthesized compounds was tested by TLC on aluminum Silica Gel-G plates, using suitable developing solvent and visualized in UV-chamber.

\section{Methodology}

Our present work reports the synthesis of Isatin-3-phenylhydrazone (IPH) and later complexation with $\mathrm{Cr}(\mathrm{III})$ metal salt. All the solutions employed were prepared in purified ethanol except metal salt solution prepared in double-distilled water. Equimolar solutions were prepared as Solution A; ethanolic solution of Isatin $(0.147 \mathrm{~g}, 10 \mathrm{mmol})$, Solution B; ethanolic solution of phenylhydrazine hydrochloride $(0.144 \mathrm{~g}, 10 \mathrm{mmol})$.

\section{Synthesis of Schiff Base Ligand L (IPH)}

$5 \mathrm{~mL}$ of solution A was added to $5 \mathrm{~mL}$ of solution B with constant stirring with a condensing agent and 3-4 drops of glacial acetic acid. This reaction mixture was continuously stirred for about 20 minutes. No precipitate is seen, after that, the content of this reaction mixture was allowed to pour in a $250 \mathrm{~mL}$ Round Bottomed flask and was refluxed at constant temperature $\left(55^{\circ} \mathrm{C}\right)$. After $10-15$ minutes, the yellow-colored compound started to deposit on the flask's inner wall. This reaction mixture was refluxed until the mixture's color changed from reddish yellow to light yellow (approx. 4.30 hours). The mixture cooled and kept overnight at room temperature, after, a yellow-colored solid product appeared, further recrystallized using ethanol, and thoroughly dried in airtight desiccators. Yellowcolored crystals were obtained with an $85.4 \%$ yield. Plausible reaction scheme for Schiff base ligand L (IPH) (Scheme-1).

\section{Synthesis of Schiff Base Metal Complex $\left[\mathrm{ML}_{2} \mathrm{Cl}_{2}\right]$}

The conventional standard procedure was adopted here, $5 \mathrm{~mL}$ of above-prepared ligand (IPH) $(0.474 \mathrm{~g}$, $20 \mathrm{mmol})$ and $5 \mathrm{~mL}$ of an aqueous solution of $\mathrm{CrCl}_{3} \cdot 6 \mathrm{H}_{2} \mathrm{O}(0.266 \mathrm{~g}, 10 \mathrm{mmol})$ were mixed with constant stirring. No precipitate was observed, then the reaction mixture refluxed at $55^{\circ} \mathrm{C}$ for about 3.30 hours. After accomplishment of reaction which was monitored by TLC, the solid product obtained was filtered, washed, recrystallized, and dried adequately in a desiccator. Deep brown colored crystals were obtained with a $75.6 \%$ yield. Proposed reaction scheme for Schiff based metal complex $\left(\mathrm{ML}_{2} \mathrm{Cl}_{2}\right)($ Scheme-2)

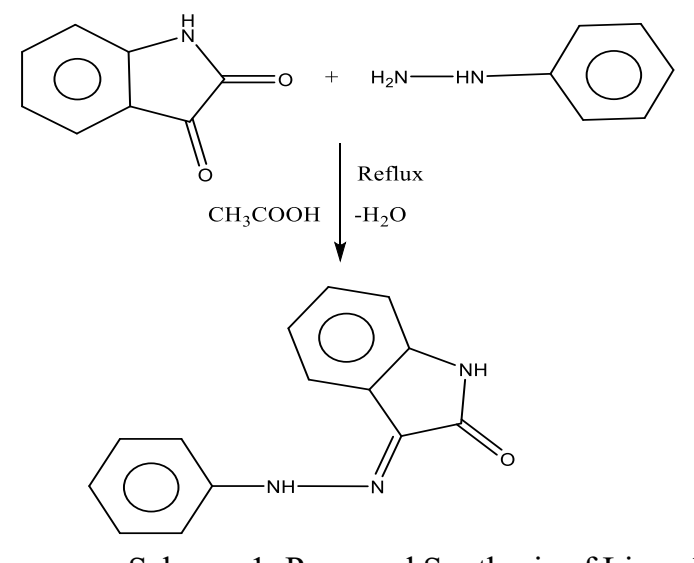

\section{Antimicrobial Study}

Scheme-1: Proposed Synthesis of Ligand

For antimicrobial activity in vitro, both ligand and complex were investigated against various bacterial and fungal strains to determine the growth-inhibiting potential employing the Cup-Plate method. ${ }^{15}$ To evaluate above, one Gram (+ive) bacterium, i.e., S. aureus (MTCC-96), one Gram (-ive) bacterium, i.e., P.mirabilis (MTCC-425), and one fungal pathogen, i.e., C. albicans (MTCC-227) were selected. For evaluating antibacterial potential, Nutrient agar was used, whereas, for antifungal study, Malt Yeast agar was employed as culture media. For antibacterial and antifungal studies, Norfloxacin and Clortrimazole were selected as standard drugs, respectively. Also, sterilization of Petri dishes, other glassware, and culture media was done by autoclaving. For performing an antibacterial evaluation, the incubation period was kept 48 hours at $37 \pm 2^{\circ} \mathrm{C}$. In contrast, for antifungal assessment, the incubation period was kept 72 hours at $25 \pm 2^{\circ} \mathrm{C}$. Test solution of synthesized compounds $(100 \mu \mathrm{g} / \mathrm{mL}, 50 \mu \mathrm{g} / \mathrm{mL})$ were made with definite concentration by dissolving in DMF. Lastly, a measurement of the inhibition zone was made, and the diameters in $\mathrm{mm}$ were calculated after incubation. 

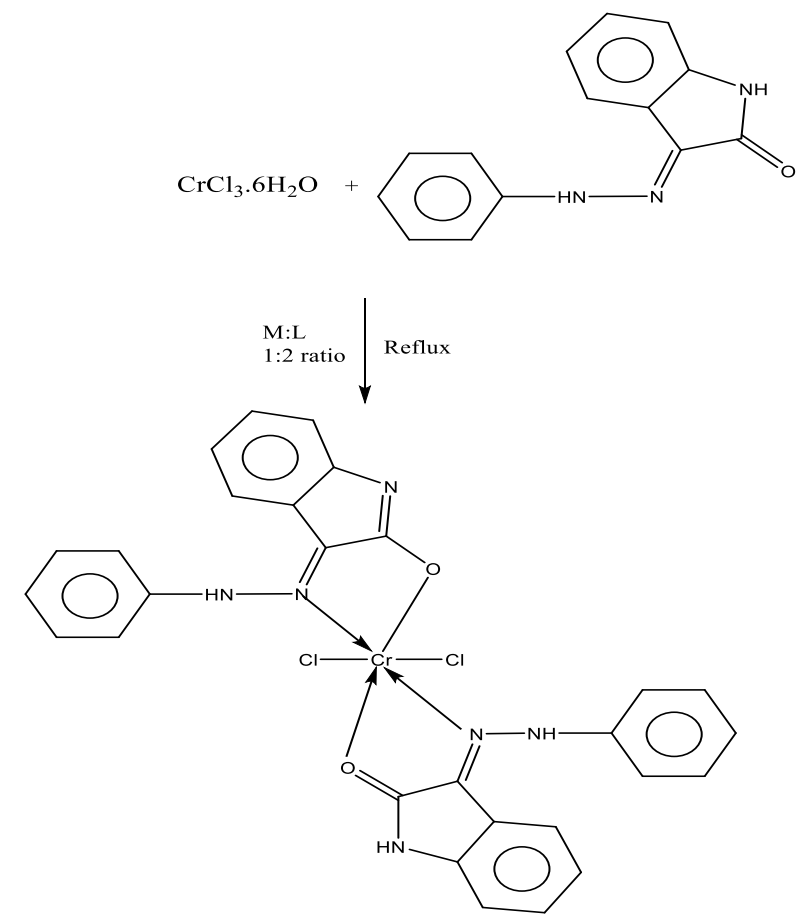

Scheme-2: Proposed Synthesis of Schiff Based Metal Complex [ $\left.\mathrm{ML}_{2} \mathrm{Cl}_{2}\right]$

\section{RESULTS AND DISCUSSION}

Physiochemical Analysis of ligand and the complex were compared and tabulated in Table-1. Both ligand and complex are colored, soluble in methanol, ethanol, chloroform, DMSO and DMF. As shown (Table-1), Elemental Analysis reveals that observed data are in satisfactory agreement with calculated data. Molecular weights obtained supports the monomeric nature of the complex. Magnetic moment $\left(\mu_{\text {eff }}\right)$ measurement for $\mathrm{CrL}_{2} \mathrm{Cl}_{2}$ was obtained $\sim 3.88 \mathrm{BM}$ expected for three unpaired electrons and the metal ion is paramagnetic. Molar conductivity measured for the complex was $\sim 12.64 \mathrm{ohm}^{-1} \mathrm{~cm}^{2} \mathrm{~mol}^{-1}$, suggesting non-electrolytic behavior (Table-1). Stoichiometry revealed a 1:2 metal-ligand ratio in the synthesized complex.

Table-1: Physicochemical and Elemental Analysis of Synthesized Compounds

\begin{tabular}{|c|c|c|c|c|c|c|c|c|c|c|}
\hline \multirow{2}{*}{$\begin{array}{l}\text { Compound } \\
\text { (Ligand/Co } \\
\text { mplex) } \\
\text { Empirical } \\
\text { Formula }\end{array}$} & \multirow{2}{*}{$\begin{array}{l}\text { Colour/ } \\
\text { M.P. }\end{array}$} & \multirow{2}{*}{$\begin{array}{l}\text { Molecular } \\
\text { Weight } \\
\text { Found } \\
\text { (Cal.) }\end{array}$} & \multicolumn{6}{|c|}{ \% Elemental Analysis Found (Cal.) } & \multirow{2}{*}{$\begin{array}{c}\text { Molar } \\
\text { Cond. } \\
\left(\mathrm{ohm}^{-1}\right. \\
\mathrm{cm}^{2} \\
\left.\mathrm{~mol}^{-1}\right) \\
\text { appr. }\end{array}$} & \multirow{2}{*}{$\begin{array}{l}\mu_{\text {eff }} \\
(\mathrm{BM}) \\
\text { Appr. }\end{array}$} \\
\hline & & & $\mathrm{C}$ & $\mathrm{H}$ & $\mathrm{N}$ & $\mathrm{O}$ & $\mathrm{Cl}$ & $\mathrm{Cr}$ & & \\
\hline $\begin{array}{l}\mathrm{L}(\mathrm{IPH}) \\
\mathrm{C}_{14} \mathrm{H}_{11} \mathrm{~N}_{3} \mathrm{O}\end{array}$ & $\begin{array}{c}\text { Yellow } \\
200.5^{\circ} \mathrm{C}\end{array}$ & $\begin{array}{c}237.30 \\
(237.26)\end{array}$ & $\begin{array}{c}70.98 \\
(70.87)\end{array}$ & $\begin{array}{l}4.72 \\
(4.67)\end{array}$ & $\begin{array}{c}17.74 \\
(17.71)\end{array}$ & $\begin{array}{c}6.78 \\
(6.74)\end{array}$ & - & - & - & - \\
\hline $\begin{array}{l}\text { Metal } \\
\text { Complex } \\
{\left[\mathrm{CrL}_{2} \mathrm{Cl}_{2}\right]} \\
\mathrm{C}_{28} \mathrm{H}_{21} \mathrm{~N}_{6} \mathrm{O}_{2} \\
\mathrm{Cl}_{2} \mathrm{Cr}\end{array}$ & $\begin{array}{c}\text { Deep } \\
\text { Brown } \\
210.4^{\circ} \mathrm{C}\end{array}$ & $\begin{array}{c}596.31 \\
(596.40)\end{array}$ & $\begin{array}{c}56.52 \\
(56.39)\end{array}$ & $\begin{array}{c}3.37 \\
(3.54)\end{array}$ & $\begin{array}{c}14.11 \\
(14.09)\end{array}$ & $\begin{array}{c}5.30 \\
(5.36)\end{array}$ & $\begin{array}{c}11.72 \\
(11.89)\end{array}$ & $\begin{array}{c}8.60 \\
(8.72)\end{array}$ & 12.64 & 3.88 \\
\hline
\end{tabular}

\section{Spectral Characterization}

FTIR spectra of synthesized compounds recorded (range of 4000-400 $\mathrm{cm}^{-1}$ ) provide interesting information displaying the nature of azomethine $(\mathrm{C}=\mathrm{N})$ linkage attached to the metal ion. The Schiff base metal complex exhibited a significant absorption band at $1615 \mathrm{~cm}^{-1}$ compared to $1622 \mathrm{~cm}^{-1}$ in the free ligand. The shift of $v(\mathrm{C}=\mathrm{N})$ to a comparatively lower frequency in the metal-ligand complex supports coordination of azomethine- $\mathrm{N}$ atom of these ligands to the central metal atom. Broadband appears at $3438 \mathrm{~cm}^{-1}$ and $3431 \mathrm{~cm}^{-1}$ in ligand and complex, respectively, that can be assigned for the $\mathrm{N}-\mathrm{H}$ group. In the metal-ligand complex, the absorption band for $\mathrm{C}=\mathrm{C}$ was observed at $1456 \mathrm{~cm}^{-1}$ (str.) with a sharp peak shifted towards lower frequency compared to that of a free ligand that appears 
at $1572 \mathrm{~cm}^{-1}$. Some weaker bands also appear at $2929 \mathrm{~cm}^{-1}$ and $2922 \mathrm{~cm}^{-1}$ in FTIR spectra of ligand and complex, respectively, due to $v(\mathrm{C}-\mathrm{H})$ bond. Furthermore, absorption bands at 767, 732 and 453 $\mathrm{cm}^{-1}$ correspond to $\mathrm{Cr}-\mathrm{Cl}, \mathrm{Cr}-\mathrm{O}$ and $\mathrm{Cr}-\mathrm{N}$, respectively. An extra peak in complex appears at $3219 \mathrm{~cm}^{-}$ ${ }^{1}$, which is supposedly due to the presence of $v(\mathrm{O}-\mathrm{H})$ of enol form of ligand. (Table-2) (Fig.-1). The ligand's U.V./Vis spectrum exhibits two strong bands at $295 \mathrm{~nm}$ for $\pi-\pi *$ transition and $375 \mathrm{~nm}$ for the $\mathrm{n}-\pi *$ transition. Above absorption bands show bathochromic shift for metal complex and the spectra show intense $\pi-\pi *$ transition band at $300 \mathrm{~nm}$ whereas weak $\mathrm{n}-\pi *$ transition band at $405 \mathrm{~nm}$. These data support the bonding of ligand with a metal ion. (Table-3) (Fig.-2). 'HNMR spectra of the synthesized compounds recorded in DMSO solvent and chemical shift expressed in $\delta$ values (ppm) downfield to TMS. The NMR spectra show a single peak at $\delta 10.2 \mathrm{ppm}$ for N(3)-H in the complex. This supports amido-iminol tautomerism and defines the bonding of oxygen anion (deprotonated form) to the metal ion. Tautomerism could also be confirmed by the disappearance of a signal in the range of $\delta 9.62-9.84$ ppm that should appear due to the N(1)-H proton of the indole ring. The protons of both benzene rings give multiplets in a range of $\delta 6.84-7.49$ ppm(Table-4) (Fig.-3).

Table-2: Selected FTIR Spectral Data $v\left(\mathrm{~cm}^{-1}\right)$ of Synthesized Ligand and Complex

\begin{tabular}{l|c|c|c|c|c|c}
\hline Compound & $v(\mathrm{~N}-\mathrm{H})$ & $v(\mathrm{C}=\mathrm{N})$ & $\begin{array}{c}v \\
(\mathrm{C}=\mathrm{C})\end{array}$ & $v(\mathrm{M}-\mathrm{N})$ & $v(\mathrm{M}-\mathrm{O})$ & $v(\mathrm{M}-\mathrm{Cl})$ \\
\hline $\mathrm{L}(\mathrm{IPH})$ & 3438 & 1622 & 1572 & - & - & - \\
\hline $\mathrm{CrL}_{2} \mathrm{Cl}_{2}$ & 3431 & 1615 & 1456 & 453 & 732 & 767 \\
\hline
\end{tabular}

Table-3: U.V. Spectral Bands (nm) of Ligand and Complex

\begin{tabular}{c|c|c}
\hline Compound & $\pi-\pi *$ & $\mathrm{n}-\pi *$ \\
\hline $\mathrm{L}(\mathrm{IPH})$ & 295 & 375 \\
\hline $\mathrm{CrL}_{2} \mathrm{Cl}_{2}$ & 300 & 400 \\
\hline
\end{tabular}

Table-4: Important ${ }^{1}$ HNMR Spectral Data $\delta(\mathrm{ppm})$ of Complex

\begin{tabular}{c|c|c}
\hline Compound & $\mathrm{N}(3)-\mathrm{H}$ & $\mathrm{Ar}-\mathrm{H}$ \\
\hline $\mathrm{CrL}_{2} \mathrm{Cl}_{2}$ & 10.2 & $\begin{array}{c}6.84-7.49 \\
\text { (multiplet) }\end{array}$ \\
\hline
\end{tabular}
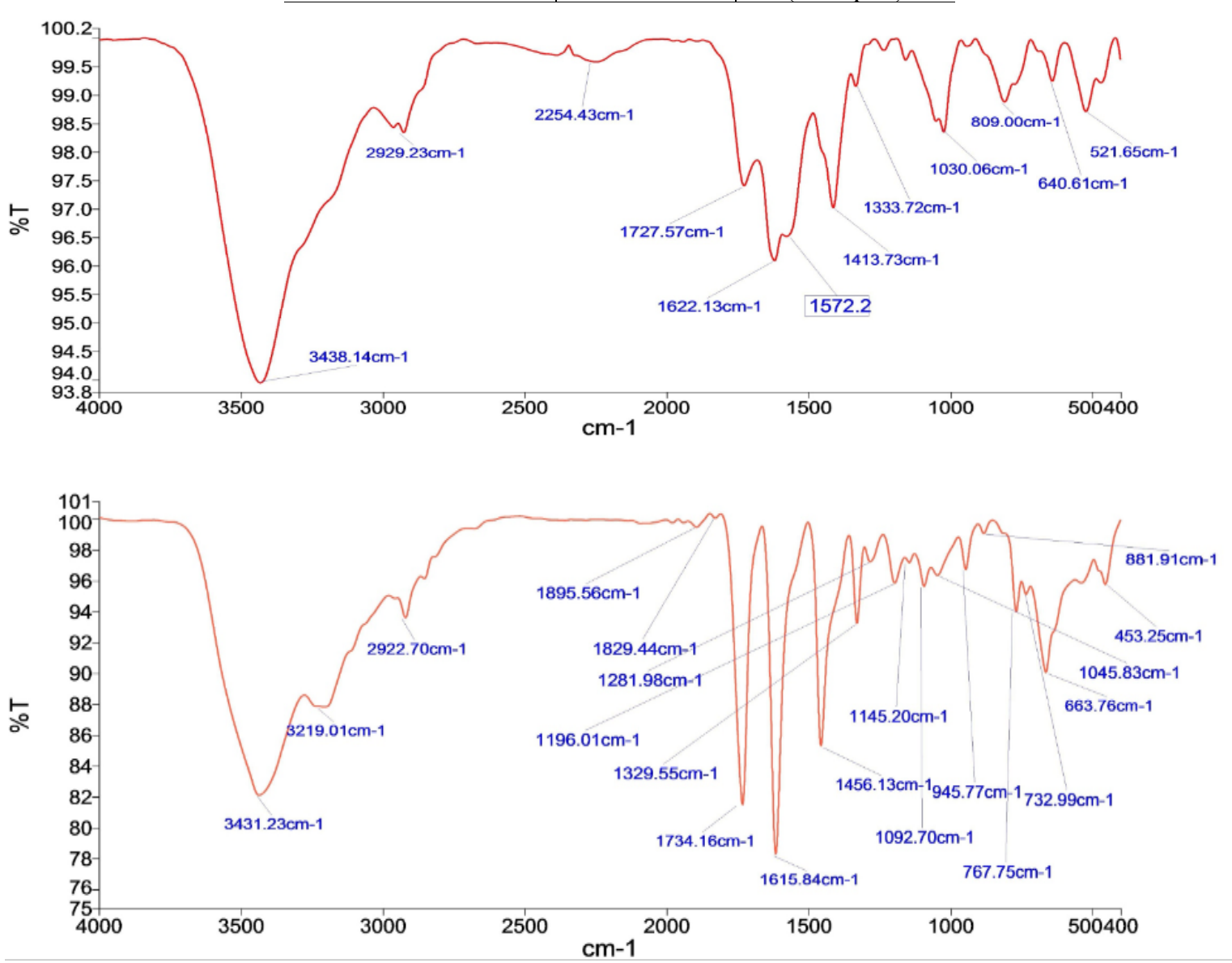

Fig.-1: FTIR Spectra of Ligand and Complex 

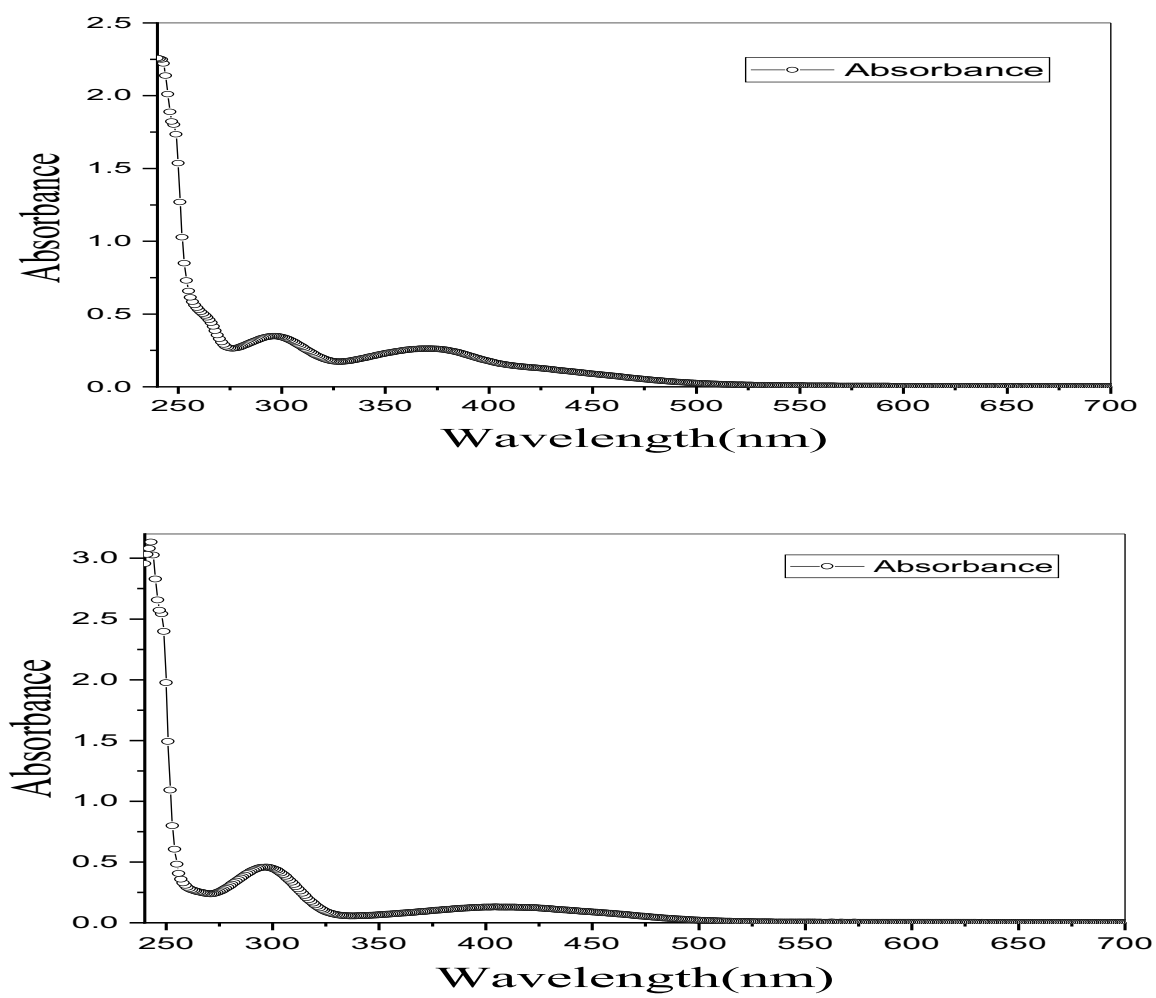

Fig.-2: U.V. Spectrum of Ligand and Metal Complex

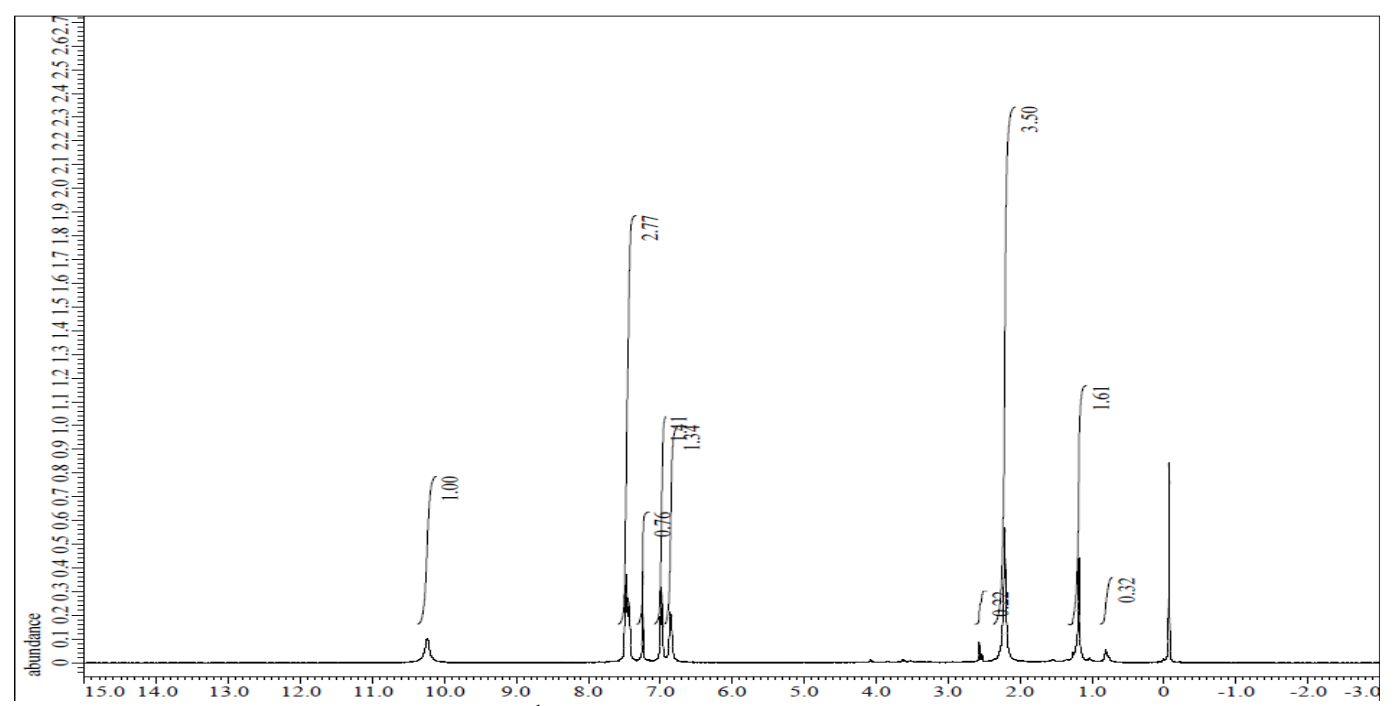

Fig.-3: ${ }^{1}$ HNMR Spectrum of Complex

Biological screening performed reveals that ligand can inhibit S.aureus and P.mirabilis's growth to a comparable extent but the less inhibiting potential for C.albicans. However, after coordination to the metal ion, the growth-inhibiting potential increases remarkably in almost all cases compared to standard (Table-5).

\begin{tabular}{c|c|c|c|c}
\hline \multicolumn{5}{c}{ Table-5: Antimicrobial Activity of Test Compounds } \\
\hline \multirow{2}{*}{ Test Compounds } & \multirow{2}{*}{$\begin{array}{c}\text { Conc. } \\
(\mu \mathrm{g} / \mathrm{mL})\end{array}$} & \multicolumn{3}{|c}{ Zone of Inhibition $(\mathrm{mm})$} \\
\cline { 3 - 5 } & & Antibacterial Activity & Antifungal Activity \\
\cline { 3 - 5 } & 100 & 31 & 28 & C.albicans \\
\hline $\mathrm{L}(\mathrm{IPH})$ & 50 & 19 & 19 & 21 \\
& 100 & 38 & 39 & 15 \\
\hline $\mathrm{CrL}_{2} \mathrm{Cl}_{2}$ & 50 & 22 & 24 & 18 \\
& 50 & 18 & 19 & $\mathrm{NT}$ \\
\hline Norfloxacin & 50 & $\mathrm{NT}$ & $\mathrm{NT}$ & 16 \\
\hline
\end{tabular}




\section{CONCLUSION}

Based on all analytical evidence, an octahedral geometry is being predicted for the above-synthesized complex. The complex is presumed to be non-electrolyte, and the metal ion is paramagnetic. In FTIR spectra of complex, shifting of $\mathrm{C}=\mathrm{N}$ towards lower wave number confirms coordination of $\mathrm{C}=\mathrm{N}$ moiety to the metal ion. Ligand is supposed to exist both in lactam and enol form in different proportions in the solution state, but the lactam form is more stable. The ligand may act as neutral or monoionic bidentate depending upon its tautomeric form involved in complexation. Mononuclear complex formation is accompanied by coordination of metal to ligand existing in two tautomeric forms showing amido-iminol tautomerism. Antimicrobial studies conclude ligand exhibiting remarkable antibacterial activity against selected bacterial strains and moderate antifungal activity against the fungal pathogen compared to standard but enhanced activity after complexation. It can be suggested by penetrating effect of test compound that may act either by killing the microbe or by blocking their active sites. Further, we are interested in recognizing pharmacophores responsible for the efficiency of any drug and developing more derivatives of isatin moiety that may enhance efficiency with minimum side effects in biological systems.

\section{ACKNOWLEDGMENT}

All authors are grateful to the Chemistry Department, the University of Rajasthan at Jaipur, for furnishing research facilities, instruments, equipment, and chemical requirements. We are very thankful to MNIT, Jaipur also for spectral studies and Department of Botany, JNV University, Jodhpur for biological studies.

\section{REFERENCES}

1. D. Visagaperumal, J.E. Ezekwem, H. Munji and V. Chandy, Pharmatutor, 6(5), 38 (2018), DOI:10.29161/PT.v6.i5.2018.38

2. N. P. Singh, K. Kumar, A. Kumar and U. Agarwal, Rasayan Journal of Chemistry, 13(1), 215(2020), DOI:10.31788/RJC.2020.1315571

3. G. Puthilibai, and S. Vasudhevan, Rasayan Journal of Chemistry, 12(2), 855(2019), DOI:10.31788/RJC.2019.1225184

4. S.K. Sandra, K. Agnes, C.R. Blaga and D. Andrea, Chemical Industry \& Chemical Engineering Quarterly, 14(1), 27 (2008)

5. R. Sundararajan and K. Lahari, International Journal of Research in Pharmaceutical Sciences, 10(2), 955 (2019), DOI:10.26452/ijrps.v10i2.367

6. M.S. Alam, D.K. Chaudhary, S. Ahmad and S. Maity, Der Pharmacia Lettre, 5(1), 285 (2013)

7. U.K. Singh, S.N. Pandey, A. Singh, B.K. Srivastava and M. Pandeya, International Journal of Pharmaceutical Sciences and Drug Research, 2, 151 (2010)

8. M. Sahihovic, M. Pazalja, I.M. Dizdarevic, A. J. Mujkic, J. Suljagic, S.S. Halilovic and A. Sapcanin, Rasayan Journal of Chemistry, 11(3), 1074(2018), DOI:10.31788/RJC.2018.1133077

9. M.O. Shibinskya, S.A. Lyakhov, A.V. Mazepa, S.A. Andronati, A.V. Turovc, N.M. Zholobakd and N.Y. Spivakd, European Journal of Medicinal Chemistry, 45, 1237 (2010), DOI:10.1016/j.ejmech.2009.12.014

10. L. Hoyun, V.R. Solomon and H. Changkun, Bioorganic \& Medicinal Chemistry, 17, 7585 (2009), DOI:10.1016/j.bmc.2009.08.068

11. S.N. Pandey, D. Sriram, G. Nath and E.D. Clercq, Indian Journal of Pharmaceutical Sciences, 61, 358 (1999)

12. G. Ozlen, K. Nilgun and S. Aydin, Bioorganic \& Medicinal Chemistry, 16, 8976 (2008), DOI:10.1016/j.bmc.2008.08.050

13. S.B. Gummadi, R. Nanam, S.M. Puttireddy, S. Bethi, K. Umasankar and V.R. Jupally, Der Pharma Chemica, 2, 196 (2010)

14. P.S. Prince, S.N. Pandeya, R.K. Roy, K. Anurag Verma and S. Gupta, International Journal of ChemTech Research, 1, 758 (2009)

15. A.L. Barry, The antimicrobial susceptibility test; Practical and Practices, First Edition, Illus Leo and Febriger, Philadelphia, p. 180 (1976)

[RJC-6007/2021] 